\title{
Comparative Water and Nutrient Application Rates among Ornamental Operations in Maryland
}

\author{
John C. Majsztrik ${ }^{1}$ \\ Department of Plant and Environmental Sciences, E-143 Poole Ag. Science \\ Building, Clemson University, Clemson, SC 29621
}

\author{
Andrew G. Ristvey \\ Wye Research and Education Center, 124 Wye Narrows Drive, Queenstown, \\ MD 21658-0169
}

\begin{abstract}
David S. Ross
Department of Environmental Science and Technology, 1426 Animal Sciences/Agricultural Engineering Building, University of Maryland, College Park, MD 20742-3234
\end{abstract}

\section{John D. Lea-Cox \\ Department of Plant Sciences and Landscape Architecture, 2102 Plant Sciences Building, University of Maryland, College Park, MD 20742}

Additional index words. nitrogen, phosphorus, irrigation management, fertilizer rates

\begin{abstract}
Quantifying the range of fertilizer and irrigation application rates applied by the ornamental nursery and greenhouse industry is challenging as a result of the variety of species, production systems, and cultural management techniques that are used. To gain a better understanding of nutrient and water use by the ornamental industry in Maryland, 491 potential operations (including multiple addresses and contacts) in the state were mailed a packet of information asking for their voluntary participation. Of the 491 potential operations, it was determined that 348 operations were currently in operation. Of those 348 operations, 48 (14\% of the operations in the state) participated in a site visit and an in-depth interview, and a detailed site analysis of the water and nutrient management practices was performed on a production management unit (MU) basis. The authors define an MU as a group of plants that is managed similarly, particularly in regard to nutrient and irrigation application. Greenhouse operations reported, on average, 198, 122, and $196 \mathrm{~kg} / \mathrm{ha} /$ year of nitrogen $(\mathrm{N})$, phosphorus $\left(\mathrm{P}\right.$, as $\left.\mathrm{P}_{2} \mathrm{O}_{5}\right)$, and potassium $\left(\mathrm{K}\right.$, as $\left.\mathrm{K}_{2} \mathrm{O}\right)$ fertilizer used, respectively, for 27 operations, representing 188 MUs. Twenty-seven outdoor container nursery operations had a total of $162 \mathrm{MUs}$, with an average of 964, 390, and $556 \mathrm{~kg} / \mathrm{ha} /$ year of $\mathrm{N}, \mathrm{P}_{2} \mathrm{O}_{5}$, and $\mathrm{K}_{2} \mathrm{O}$ fertilizer used, respectively. Field nursery (soil-based) operations were represented by 17 operations, producing $96 \mathrm{MUs}$, with an average of 67,20 , and $25 \mathrm{~kg} / \mathrm{ha} / \mathrm{year}$ of $\mathrm{N}, \mathrm{P}_{2} \mathrm{O}_{5}$, and $\mathrm{K}_{2} \mathrm{O}$ fertilizer used, respectively. Irrigation volume per application was greatest in container nursery operations, followed by greenhouse and field nursery operations. Data were also analyzed by creating quartiles, which represent the median of the lowest $25 \%$, the middle $\mathbf{5 0 \%}$, and highest $\mathbf{7 5 \%}$ of values. It is likely that the greatest quartile application rates reported by growers could be substantially reduced with little to no effect on plant production time or quality. These data also provide baseline information to determine changes in fertilization practices over time. They were also used as inputs for water and nutrient management models developed as part of this study. These data may also be useful for informing nutrient application rates used in the Chesapeake Bay nutrient modeling process.
\end{abstract}

Irrigation is typically required for ornamental production operations, especially if operations are growing containerized stock (Warsaw et al., 2009). Effective water management is the key to reducing nutrient leaching and runoff from these operations

Received for publication 6 Nov. 2017. Accepted for publication 25 Mar. 2018.

${ }^{1}$ Corresponding author. E-mail: jmajszt@clemson. edu. irrigation water at the correct time to maintain optimal growth rates is very challenging for greenhouse and container nursery production. Rooting (container) volumes are typically limited, substrates differ in waterholding capacity, and plant water use changes in response to daily environmental conditions and is species dependent (Belayneh et al., 2013; Owen et al., 2008; van Iersel et al., 2013). Irrigation scheduling decisions are often based on past experience and integration of tangible factors (container weight, plant condition and size, time from prior irrigation, and environmental conditions) rather than actual plant water use, which is difficult for growers to determine quickly and accurately (Lea-Cox, 2012).

Although there are general guidelines for growers to follow when creating an irrigation and fertility program for ornamental nursery production, actual practices are often a combination of experience and research. Understanding typical irrigation and fertilization practices in ornamental production can help identify areas in which management practices can be changed without negatively impacting production schedules or plant health. Collecting information on current production practices can help inform growers, researchers, and extension and government agencies regarding variability in practices. This information can also be used to help inform legislation and modeling efforts, such as those currently underway in the Chesapeake Bay watershed (Majsztrik and Lea-Cox, 2013).

The Chesapeake Bay is subject to Environmental Protection Agency-mandated total maximum daily load limits for nitrogen $(\mathrm{N})$, phosphorus $(\mathrm{P})$, and sediment for all 94 watershed segments (by eight-digit hydrologic unit code) to remove the Bay and its tributaries from the impaired waters list by 2025 (Sincock, 2010). About 25\% (3.4 million ha) of the Bay's watershed is used for agriculture, constituting the largest actively managed land use (Environmental Protection Agency, 2009). Maryland has $\approx 0.5$ million ha of farmland, with nursery and greenhouse operations accounting for $\approx 12,000$ of 38,000 irrigated hectares, adding $\$ 245$ million in total sales (U.S. Department of Agriculture, 2010) and contributing substantially to the agricultural economy of Maryland (Dawson et al., 2009; Environmental Protection Agency, 2009).

As a result of the Maryland Water Quality Improvement Act of 1998, all commercial greenhouse and nursery operations in the state are required to develop and implement an $\mathrm{N}$ - and P-based nutrient management plan (Lea-Cox et al., 2001). Because of the complexity of these operations and the large number and diversity of ornamental species grown by most operations, the nutrient management process uses a risk assessment strategy based on $\mathrm{N}, \mathrm{P}$, irrigation application, and surface water runoff risk, not on a crop nutrient removal basis, as is used for agronomic crops (Lea-Cox and Ross, 2001). This process assesses the potential for $\mathrm{N}$ and $\mathrm{P}$ runoff from individual operations based on nomic consequences for the grower supplies are usually available, and irrigation typically constitutes a very small tion of the overall cost structure of an operation (Majsztrik et al., 2011). Overapplication of water is not benign and can lead to nutrient leaching, increasing surface water runoff, erosion, and root diseases (Lea-Cox et al., 2013). Applying the correct volume of 
their specific management practices, and provides guidance for the development and implementation of additional best management practices (BMPs), which are defined in this article as practices that minimize water and chemical misapplication and pollution, if necessary (Lea-Cox et al., 2001). Because nursery and greenhouse production systems are input intensive, they have the potential to contribute $\mathrm{N}$ and $\mathrm{P}$ to the surrounding environment, if appropriate management and water-control structures are not in place.

There has been minimal research that has focused on defining $\mathrm{N}$, $\mathrm{P}$, and sediment contributions from the commercial nursery and greenhouse industry, and on quantifying the impact of ornamental operations on local watersheds and the Chesapeake Bay. There has been some general work on nonpoint source runoff (which includes ornamental production) (Blalock and Smolen, 1990). Headley et al. (2001) looked at nutrient removal using subsurface flow wetlands, whereas Hong et al. (2009) focused on ornamental runoff quality in the Chesapeake Bay watershed. Quantifying nutrient runoff is resource intensive and expensive; and, more importantly, most production operations have unique nutrient management and runoff mitigation controls, which make comparisons among operations difficult. As states and regions continue to search for ways to reduce nonpoint source contaminants (e.g., $\mathrm{N}, \mathrm{P}$, sediment), information from regulated areas such as the Chesapeake Bay region may be able to inform other growers, researchers and regulators.

There are few data in the literature on actual commercial $\mathrm{N}$ and $\mathrm{P}$ (measured in kilograms per hectare per year) and water application (measured in liters per hectare) rates for the nursery and greenhouse industries, in contrast to research studies investigating various aspects of plant-nutrient interactions (Majsztrik et al., 2011; Owen et al., 2008; Sandrock et al., 2004). Yeager et al. (1993) published $\mathrm{N}$ runoff data from a six-state survey of container nursery operations to calculate the potential impact of $\mathrm{N}$ runoff. However, application rates and runoff volumes were not a part of this study. Water usage data were reported by Hutson et al. (2004), but are not broken down any further than at the state level. Santos et al. (2008) quantified water volume and nutrient leaching during propagation of calibrachoa (Calibrachoa $\times$ hybrida) and petunia (Petunia $\times$ hybrida) liner trays, with rates varying from 0.5 to $80 \mathrm{mg} \cdot \mathrm{L}^{-1}$ of $\mathrm{N}$ and water leaching from 4.5 to $46.1 \mathrm{~L} \cdot \mathrm{m}^{-2}$. Mangiafico et al. (2009) reported an average $\mathrm{N}$ runoff rate of $5.7 \mathrm{mg} \cdot \mathrm{L}^{-1}$ from seven surveyed nurseries in Ventura County, CA, but these studies included relatively few operations, species, or details on specific practices. There are a broad range of commercial fertilizers and fertigation practices. The objective of this research was to gain a better understanding of Maryland on-farm irrigation and fertilization application rates at the MU level, to better understand irrigation and fertilization types, rates, and variability within and among growers.

\section{Materials and Methods}

Information packets about the project were mailed to 491 potential addresses, collated from Department of Agriculture and State Landscape Association contact lists. These lists included duplicates, multiple addresses, and multiple contacts for the same operation. We determined that there were 348 commercial nursery and greenhouse operations in business in the state. This correlated well with the U.S. Department of Agriculture specialty crops census (U.S. Department of Agriculture, 2010) that reported 368 commercial nursery and greenhouse operations in Maryland in 2007. A human subjects Institutional Review Board review was completed and approved before any growers were contacted. Specific details about sampling protocols, interview forms, and institutional review board information are included in Majsztrik (2011).

Nutrient management plan information is collected by the Maryland Department of Agriculture, the agency responsible for regulating nutrient management programs in the state. Information packets about the project were mailed to these 348 operations; 48 agreed to share their nutrient management plans voluntarily either by allowing access to Maryland Department of Agriculture records or by allowing review of records at their operation.

Many nutrient management plans were written initially between 2002 and 2005 . By 2009 , there was the potential for these plans to have outdated information as a result of change in practice, which would not necessarily have required a revised management plan to be submitted. In addition, most submitted nutrient management plans did not contain adequate information on a crop-bycrop basis, or any information on irrigation type/frequency, which is necessary for a complete understanding of potential water and nutrient runoff. Thus, operational site visits and grower interviews were determined to be the most effective way of capturing relevant data required for this study and subsequent modeling efforts. Interviews were performed onsite February through April 2009.

Growers were asked a series of detailed questions about their operation, including total operation size, size of greenhouse, container nursery and field nursery areas, and rainfall/irrigation runoff and collection practices (Fig. 1) [see Majsztrik (2011) for the complete data collection form]. Information was also collected about each MU at the operation, including species of plant, area under production, irrigation type and specifications, minutes of irrigation per cycle, days irrigated per week, number of plants, container size and spacing, substrate used, fertilizer type and the nitrogen-to-phosphorus-to-potassium (K) ratio, fertilizer application rate, and timing. Data were converted to a consistent format (e.g., parts per million, gallons per minute, milligrams per liter) for analyses. In general, growers were willing to discuss their operation and its management, and were open and receptive to questions during the interviews. Interviews typically lasted 1 to $3 \mathrm{~h}$, depending on the size and complexity of the operation.

During the interviews, some growers did not have specific knowledge about some aspects of their operations, such as exact MU size, irrigation frequency, volume per minute, or volume per hour per emitter, but could give estimates or general ranges for the MUs. Therefore, the numbers given in the database may be slightly different from exact practice, but are assumed to be reasonably accurate. Although other methods, such as onsite season-long data collection, or having growers complete daily or weekly logs of practices, might have yielded more accurate data, the expense and labor were impractical to gather this information. Grower interviews, supported by nutrient management plan information, were believed to provide information sufficient for the scope and objectives of this project.

We define an MU as a group of plants that is managed similarly, mainly in terms of production areas or container size, water and nutrient application rates, and timing. MUs may or may not be located at the same location in an operation (i.e., can be noncontiguous) or grown at the same time in the year. Thus, an MU represents the smallest division of an operation that is managed in the same way. Some examples of MUs were propagation beds, bedding plants, 11.3-L containers with $38.1-\mathrm{cm}$ centers, and 56.7-L containers on drip.

Separate databases were created for greenhouse, container nursery, and field nursery operations. These operational databases contain information about all MUs, such as area, container size, number of plants, plant type/species, production goal, frequency and type of fertilizer(s) applied, plant spacing, irrigation type and practices, substrate type, and specific BMPs used. To be included in summary tables, there had to be at least four MUs and two operations represented, so lesser used practices were not portrayed as common. A general database was also developed that included data on operation size, production area, total $\mathrm{N}$, phosphate $\left(\right.$ as $\left.\mathrm{P}_{2} \mathrm{O}_{5}\right)$, and potassium (as $\mathrm{K}_{2} \mathrm{O}$ ) applications, and macro-scale BMPs such as containment basins or vegetative buffer strips.

Quartile distributions were used to analyze data from site visits. The quartile analysis divides a dataset into three parts, with the lower quartile being the median of the lowest $25 \%$ of values and the middle quartile equaling the median of the middle $50 \%$ of the values $(26 \%$ to $75 \%)$; the median of the highest $25 \%$ ( $76 \%$ to $100 \%)$ of the values is the upper quartile (Ott and Longnecker, 2001). Quartiles were used as descriptive statistics because they provide a better understanding of the range of practices involved at different operations, compared with minimum, maximum, and average values. This is 


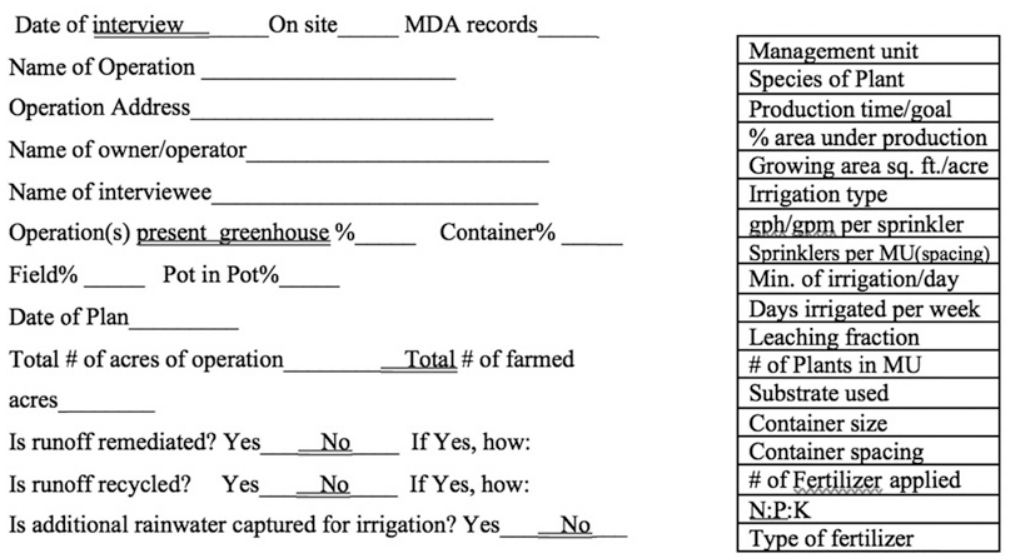

Notes: terrain, slope, and where runoff goes? How do they schedule irrigation? How often does that change? How much runoff do they have? Any known irrigation problems? (non-uniform application etc.)

Fig. 1. Condensed interview form for collecting existing water and nutrient management practices for 48 greenhouse, container nursery, and field nursery growers in Maryland. A complete interview form can be found in Majsztrik (2011).

especially useful because minimum and maximum values may be outliers, causing false inferences to be made about typical practices. The use of quartile data thus minimizes the influence of outliers on the data reported. In addition to providing information about industry irrigation and fertilization practices, data collected from growers were used to inform input values for operation-specific greenhouse, container nursery, and field nursery production models (Majsztrik, 2011).

\section{Results and Discussion}

Of the 348 operations mailed information packets, $82(22 \%)$ responses were received. Eleven operations (3\%) indicated they were no longer growing plants, 20 operations $(5 \%)$ declined participation, and 51 operations $(14 \%)$ agreed to participate in the project. Three operations that agreed to participate in the study declined to participate in the sitevisit portion of the project. Those three operations were excluded from the analysis, because there was insufficient data available in their nutrient management plans. For 47 of the 48 operations, onsite interviews were conducted; one operation that was not currently growing was interviewed over the phone, at the grower's request.

Operational data. Table 1 provides a summary of descriptive statistics based on the analysis of grower interviews. Some growers had more than one type of operation at the same site (i.e., greenhouse and container nursery). These were separated into different databases, so the total number of "operational units" sums to 71 , and total MUs equals 188, 162, and 96 for greenhouse, container nursery, and field nursery, respectively (Table 1). Greenhouse operations accounted for a total of 26 ha of production area (including multiple growing cycles using the same production area), container nurseries accounted for 72 ha of production area, with
425 ha in field nursery production (data not shown). This excluded walkways, roadways, buildings, drainage areas, and vegetative buffers. The average MU size was 0.18 ha for greenhouse, 0.45 ha for container nursery, and 4.49 ha for field nursery operations (Table 1). There were two major reasons for the differences in MU size: 1) plant density tends to decrease from greenhouse to container nursery to field nursery operations, and 2 ) increasing management intensity typically leads to more MUs, because increases in species diversity typically mandates different cultural requirements to minimize time to sale (typically the primary yield goal).

Table 1 suggests that container nursery operations have the greatest nutrient application rates at $864 \mathrm{~kg} / \mathrm{ha} /$ year, $390 \mathrm{~kg} / \mathrm{ha} /$ year, and $556 \mathrm{~kg} / \mathrm{ha} /$ year of $\mathrm{N}, \mathrm{P}_{2} \mathrm{O}_{5}$, and $\mathrm{K}_{2} \mathrm{O}$, respectively. Although these numbers are high compared with field nursery production $(20-67 \mathrm{~kg} / \mathrm{ha} /$ year $)$ and agronomic production $(60-150 \mathrm{~kg} / \mathrm{ha} /$ year for N) (Peterson and Varvel, 1989; Stewart et al., 2005), the largest differences between different types of operations were in plant density and production time. For example, corn is typically produced in 90 to $110 \mathrm{~d}$ at a density of $\approx 80,000$ plants/ha (Peterson and Varvel, 1989). In field nursery production, planting density was reported to be 1794 to 2152 plants/ha, with plants staying in the same location for a number of years (Table 2). Container nursery production averaged 19,768 to 154,941 plants/ha, with plants typically grown for 3 months to a growing season before being sold or moved to a larger container. Greenhouse production averaged 107,537 to 863,563 plants/ha, with production times from 6 to 20 weeks typical, depending on the species grown and container size. It should be noted that the large sDs seen in some of the data (Tables 1-3) are a result of variability in practices within and among growers, which can also be seen in the quartile values. The term slow-release fertilizer (SRF) is used instead of controlled release fertilizer, because these fertilizers typically show a temperature-dependent release pattern (Cabrera, 1997; Du et al., 2006; Huett and Gogel, 2000); release rates are most often not controlled under production conditions. Because container nursery operations typically only apply SRFs, greater plant densities would lead to greater nutrient application rates per hectare for these operations. In other words, the more densely spaced the containers or plants, the greater the rate of application per hectare at the same application rate per plant. Also, most SRFs are applied once during the growing season, as opposed to multiple applications that are possible in other scenarios (e.g., a corn field followed by another crop, multiple crops grown in the same location in a greenhouse). If the rates for greenhouse production in Table 1 are multiplied by three, representing three crops grown on the same physical space, rates approach those for container nursery production.

Table 2 provides summary data for plant densities by type of operation. Densities for greenhouse and container nursery plants varied about 8-fold from the lower to the upper quartile (107,537-863,563 plants/ha and 19,768-154,191 plants/ha, respectively), highlighting the variety of sizes and container spacing used in these types of operations. Field nursery operations reported much less application rate variability, because plant density does not vary as dramatically per hectare. However, it should be noted that these values do not include transplanting beds used to grow liner plants, before being planted at their final spacing.

Irrigation management. Total water application volumes per irrigation are listed in Table 3. For container nursery operations, both spring/fall and summer irrigation rates are reported to highlight seasonal differences. The volume of irrigation water applied to a given area is important because water is the transport mechanism for both nutrients and sediment at an operation (Ross et al., 2002). The overapplication of irrigation water without appropriate control measures can lead to nutrient and sediment runoff into the surrounding environment

Differences in irrigation volumes per application between greenhouse, container nursery, and field nursery operations are shown in Table 3. Greenhouse operations tend to grow greater numbers of plants in smaller containers and irrigate more precisely and more often with smaller irrigation volumes per container, leading to a lower application volume per irrigation event, but more irrigation events per day. Irrigation timing and volume have been shown to impact plant growth and quality (Belayneh et al., 2013; Delgado and Bausch, 2005; LeaCox et al., 2013; van Iersel et al., 2013; Warren and Bilderback, 2004)

Greenhouse operations applied half or less than half as much irrigation on a perhectare basis compared with container 
nursery operations across all quartiles for both spring and summer irrigation. This greater volume in container nursery operations is most likely a result of larger container sizes in these nurseries, which require more water to maintain similar substrate water contents, compensate for larger evapotranspirational losses and coarser substrates, and reduce interception efficiencies using overhead irrigation, compared with the more precise irrigation techniques used in greenhouse operations. In addition, greenhouse operations typically apply water more frequently, but for less time compared with container nursery operations, which was observed in the number of irrigation events reported per day (data not shown). There are also environmental factors such as wind, humidity, and greater evaporation rates, which may require a longer duration of irrigation to maintain plant-available water adequately. Sensor-controlled irrigation has been shown to reduce irrigation volume applied, maintain or improve plant growth, and reduce disease incidence (Chappell et al., 2013; van Iersel et al., 2013).

A majority $(79 \%)$ of field nursery operations used drip irrigation, applying lesser volumes of irrigation over an extended period of time (data not shown). All field nursery operations that were visited had vegetative buffers between tree rows, and all operations had grass at the end of rows, which is considered a BMP to minimize soil erosion. Of the field nursery operations visited, 76 MUs (79\%) used either drip or pressurecompensating drip emitters. Irrigation in field nursery operations is typically applied several times a week, especially when newly transplanted blocks are being established (during years 1 and 2), and thereafter when needed throughout the production period. Average drip irrigation depth was found to be $2 \mathrm{~cm}(0.8$ acre-inches $=21,750$ gal $/$ acre $=$ $230,000 \mathrm{~L} \cdot \mathrm{ha}^{-1}$ ) per irrigation, with one to several irrigations per week depending on species, plant age, and environmental conditions.

Twenty-three MUs, across all three types of operations were excluded from the results shown in Table 3 because growers were not sure of the application rate of the emitter or the amount of time irrigation was applied. If the grower gave a range of time that irrigation was applied, the upper range was used, to represent the maximum potential water application per irrigation event. The results (Table 3) also indicate that container nursery growers in the upper and lower quartiles did not vary the amount of water applied per irrigation cycle as much as the growers in the middle quartile. For example, the middle quartile shows a $58.1 \%$ lesser rate in the spring, compared with the summer, suggesting that growers at the extremes tend to vary their irrigation less than growers in the middle range. Irrigation rates for the middle quartile almost doubled from spring to summer, suggesting that these growers actively managed their scheduling, or adjusted more for rainfall and lower temperatures (Table 3). The major difference in irrigation application was not in the amount of time the irrigation was run, but in the frequency of applications during a typical week. Spring and fall applications per week were typically less than summer applications, which were often 3-5 d per week and 5-7 d per week respectively (data not shown). There are likely two reasons why more days were added as weather warms. First, if growers are irrigating to container capacity, there is minimal benefit of increasing irrigation length. Second, for most systems it is easier to program an extra irrigation run (day per week, or multiple irrigations per day) rather than increase the runtime of each irrigation zone.

Nutrient management. Nutrient application is a necessary part of greenhouse and container nursery production and is often used in field nursery production to maximize plant growth. Growers base fertilization decisions on previous practices, the recommendation of other growers, or fertilizer recommendations from companies or extension agents.

Greenhouse operations reported using 24 different fertilizer ratios compared with 27 for container nursery operations and 15 for field nursery operations (data not shown). In general, greenhouse operations were more likely to use different fertilizer ratios for different plant species or at different times of the year. Greenhouse fertilizer formulations were often used to regulate substrate $\mathrm{pH}$ or to create a balanced fertilizer program for particular species (data not shown). In container nursery and field nursery operations, only one or a few different $\mathrm{N}: \mathrm{P}_{2} \mathrm{O}_{5}: \mathrm{K}_{2} \mathrm{O}$ ratios were used on a wide variety of plant species, with different operations typically using different fertilizer blends (data not shown). In other words, container nursery and field nursery fertilizer ratios tended to be operation specific, whereas greenhouse fertilizer ratios tended to be more species or time specific. The only exception was in a few field nursery operations, which indicated that they applied a fertilizer with no $\mathrm{P}_{2}$ $\mathrm{O}_{5}$ because some of their soil $P$ values were high, based on soil analyses.

The top $10 \mathrm{~N}: \mathrm{P}_{2} \mathrm{O}_{5}: \mathrm{K}_{2} \mathrm{O}$ ratios reported by greenhouse, container nursery, and field nursery operations varied by operation type. Formulations and the number of MUs using each formulation are provided in Table 4. Additional data are reported in Majsztrik (2011). If more than one fertilizer ratio was used for the same MU throughout the course of growing period, each ratio was listed separately. As expected, greenhouse operations used predominantly soluble types of fertilizer (146/188 MUs, or 78\%), whereas container nursery operations mainly reported using SRF (125/162 MUs, or 77\%) (Table 4). Field nursery operations mainly used uncoated inorganic surface-applied fertilizer (70/96 MUs, or 79\%) (Table 4).

Based on species-specific data published for $\mathrm{N}$ and $\mathrm{P}$ uptake rates in ornamental plants, a ratio of $4: 1: 3$ to perhaps $8: 1: 6\left(\mathrm{~N}: \mathrm{P}_{2} \mathrm{O}_{5}\right.$ : $\mathrm{K}_{2} \mathrm{O}$ ) should optimize plant growth while reducing unused nutrient amounts in the substrate $(\mathrm{Ku}$ and Hershey, 1997a, 1997b; Ristvey, 2004; Sammons, 2008). A variety of fertilizer ratios were used in all types of operations, indicating that there is no particular ratio used more widely by growers (Table 4). Many of the reported formulations, such as $20-20-20$ or $10-20-10$, provide one or more nutrients in excess of plant requirements, leading to the potential for nutrient loss to the environment. In general, container nursery operations had formulations similar to the recommended ratio (i.e., 18-6-8, 185-11, and 18-6-12), which were mainly SRF formulations (data not shown). The 21-10 20 ratio, most often reported by greenhouse growers, does not fit this ratio, but the 17-517 ratio that was reported second-most by growers was similar (Table 4). Field nursery production used a range of fertilizer ratios, with "no fertilizer" reported most frequently, followed by $\mathrm{N}$-only formulations.

There is often a misunderstanding in the nursery and greenhouse industries that high P-ratio fertilizers preferentially promote root, shoot, or flowering and fruit growth, which has been refuted by a number of studies (Hansen and Lynch, 1998; Harris, 1992; Majsztrik et al., 2011; Williams and Nelson, 1996). This can lead to the use of "unbalanced" fertilizer formulations such as 20 20-20 or 13-13-13 fertilizers, which have superoptimal ratios of $\mathrm{P}_{2} \mathrm{O}_{5}$ compared with $\mathrm{N}$ and $\mathrm{K}_{2} \mathrm{O}$. Because many fertilizer manufacturers are now producing custom-blend fertilizers, applying specific fertilizer formulations is now possible to optimize plant nutrient uptake further, as long as appropriate rates are used. Applying fertilizers with formulations very different from the 4-1-3 ratio could result in excess nutrient runoff of one or more nutrients, because the excess nutrients would not be taken up by the plant, and therefore would be prone to leaching into surface and groundwater when water leaches out of the container or beyond the root zone (Cabrera, 2003).

Nutrient application rates are reported for eight greenhouse (Table 5), eight container nursery (Table 6), and three field nursery (Table 7) production scenarios, with additional rates reported in Majsztrik (2011). The more MUs represented in the data, the better these data should represent the true ranges of practices. The reported values represent maximum values and assume that the growing area only contains plants. They do not include production area taken up by walking/ driving rows, infrastructure, and so on, which would typically take up $10 \%$ to $40 \%$ of actual growing area.

Two sets of nutrient application rates are reported in Tables 5-7. The first set of rates do not take plant density into account, whereas the second set of $\mathrm{N}: \mathrm{P}_{2} \mathrm{O}_{5}: \mathrm{K}_{2} \mathrm{O}$ values normalizes nutrient applications by plant density, reporting nutrient usage per 1000 plants. Rates of kilograms of nutrient per 1000 plants also equates to grams of nutrient applied on a per-plant basis (Tables 5-7). Lower, middle, and upper quartile values are the median of the lowest $25 \%$, middle $50 \%$, 
Table 1. Summary of operational data based on the analysis of existing water and nutrient management plans, and onsite interviews with 48 greenhouse, container nursery, and field nursery growers in Maryland. Standard deviations are included in parentheses.

\begin{tabular}{lccc}
\hline Variable & Greenhouse $(\mathrm{n} \pm \mathrm{SD})$ & Container $(\mathrm{n} \pm \mathrm{SD})$ & Field $(\mathrm{n} \pm \mathrm{SD})$ \\
\hline No. of operations visited & 27 & 27 & 17 \\
No. of MUs & 188 & 162 & 96 \\
Average $\mathrm{MU}$ size $(\mathrm{ha})$ & 0.18 & 0.45 & 4.49 \\
Average $\mathrm{N}$ application rate $(\mathrm{kg} / \mathrm{ha} /$ year $)$ & $198^{\mathrm{z}}(350)$ & $864(522)$ & $67(42)$ \\
Average $\mathrm{P}_{2} \mathrm{O}_{5}$ application rate $(\mathrm{kg} / \mathrm{ha} /$ year) & $122^{\mathrm{z}}(276)$ & $390(223)$ & $20(27)$ \\
Average $\mathrm{K}_{2} \mathrm{O}$ application rate $(\mathrm{kg} / \mathrm{ha} /$ year) & $196^{\mathrm{z}}(350)$ & $556(305)$ & $25(34)$ \\
\hline
\end{tabular}

${ }^{\mathrm{z}}$ Average production time was 16.9 weeks, or 3.1 cycles/year (data not shown).

$\mathrm{MU}=$ management unit; $\mathrm{N}=$ nitrogen; $\mathrm{P}=$ phosphorus $\left(\right.$ as $\left.\mathrm{P}_{2} \mathrm{O}_{5}\right), \mathrm{K}=$ potassium $\left(\right.$ as $\left.\mathrm{K}_{2} \mathrm{O}\right)$.

Table 2. Plant densities (number of plants per hectare) \pm sD by operation type, based on information from 48 operations (27 greenhouses, 27 container nurseries, and 17 field nurseries) in Maryland. Densities do not take walkways and other nongrowing areas into account. Plant densities varied greatly among management units and among operations, so SDs are large. For field producers, the upper quartile included seedling beds that were grown for a year before final spacing in the field.

\begin{tabular}{llcc}
\hline & \multicolumn{3}{c}{ Avg plant density (no. of plants/ha) } \\
\cline { 2 - 4 } Quartile & \multicolumn{1}{c}{ Greenhouse } & Container & Field \\
\hline Lower & $107,537 \pm 27,806$ & $19,768 \pm 4,407$ & $1,794 \pm 301$ \\
Middle & $242,454 \pm 234,130$ & $47,938 \pm 37,928$ & $1,794 \pm 161$ \\
Upper & $863,563 \pm 7,769,821$ & $154,941 \pm 1,941,780$ & $2,152 \pm 21,569$ \\
\hline
\end{tabular}

Table 3. Volume of water applied per irrigation event \pm sD, based on information from 48 operations (27 greenhouses, 27 container nurseries, and 17 field nurseries) in Maryland. Data were collected at the management unit level (groups of plants that have the same irrigation and fertilization practices).

\begin{tabular}{lcccc}
\hline & & \multicolumn{2}{c}{ Container (L/ha/irrigation) } & \\
\cline { 3 - 4 } Quartile & Greenhouse (L/ha/irrigation) & Spring/fall & Summer & Field (L/ha/irrigation) \\
\hline Lower & $40,820 \pm 11,093$ & $79,215 \pm 22,497$ & $91,923 \pm 24,740$ & $32,597 \pm 10,607$ \\
Middle & $65,193 \pm 12,703$ & $132,921 \pm 77,031$ & $228,652 \pm 95,081$ & $42,783 \pm 34,301$ \\
Upper & $86,555 \pm 102,650$ & $325,615 \pm 568,962$ & $356,149 \pm 664,926$ & $128,349 \pm 113,043$ \\
\hline
\end{tabular}

Large sDs indicate that practices differed substantially among management units and operations.

Table 4. Top 10 ten nitrogen $(\mathrm{N})$, phosphorus $\left(\mathrm{P}\right.$, as $\left.\mathrm{P}_{2} \mathrm{O}_{5}\right)$, and potassium $\left(\mathrm{K}\right.$, as $\left.\mathrm{K}_{2} \mathrm{O}\right)$ fertilizer ratios used by 48 operations ( 27 greenhouses, 27 container nurseries, and 17 field nurseries) in Maryland, with number of management units (MUs) reported using each formulation.

\begin{tabular}{|c|c|c|c|c|c|}
\hline \multicolumn{2}{|c|}{ Greenhouse } & \multicolumn{2}{|c|}{ Container } & \multicolumn{2}{|c|}{ Field } \\
\hline $\mathrm{N}: \mathrm{P}_{2} \mathrm{O}_{5}: \mathrm{K}_{2} \mathrm{O}$ ratio & No. of MUs & $\mathrm{N}: \mathrm{P}_{2} \mathrm{O}_{5}: \mathrm{K}_{2} \mathrm{O}$ ratio & No. of MUs & $\mathrm{N}: \mathrm{P}_{2} \mathrm{O}_{5}: \mathrm{K}_{2} \mathrm{O}$ ratio & No. of MUs \\
\hline $20-10-20$ & 40 & $18-6-8$ & 15 & $0-0-0$ & 7 \\
\hline $17-5-17$ & 38 & $18-5-11$ & 13 & $20-0-0$ & 4 \\
\hline $20-20-20$ & 12 & $18-6-12$ & 13 & $8-0-0$ & 3 \\
\hline $20-7-20$ & 12 & $17-7-8$ & 12 & $10-10-10$ & 3 \\
\hline $20-5-20$ & 11 & $19-5-9$ & 12 & $15.5-0-0$ & 3 \\
\hline $17-5-24$ & 10 & $12-5-6$ & 9 & 4-6-4 & 2 \\
\hline $13-13-13$ & 8 & $13-13-13$ & 9 & $10-20-10$ & 2 \\
\hline $22-0-22$ & 8 & $17-7-12$ & 9 & $12-3-10$ & 2 \\
\hline $15-5-15$ & 7 & $17-7-14$ & 7 & $16-8-8$ & 2 \\
\hline $14-14-14$ & 6 & $18-5-9$ & 7 & $5-3-3$ & 1 \\
\hline
\end{tabular}

and upper $25 \%$ of values, respectively. Because greenhouse crops are grown for different lengths of time, the third set of values (Table 5 only) is the equivalent nutrient value per 1000 plants, as if the crop was grown for 1 year, to make comparisons between different MU types. Field nursery operations were found to have the least nutrient inputs, with container nursery operations having the greatest inputs (Tables 1 and 5-7). For greenhouse operations, application rates were less than container nurseries, but greenhouses may have three to five crop cycles in the same physical space in a given year, whereas container nursery operations typically have one MU in the same production area per year.

The application rate of soluble fertilizers in greenhouse operations ranged from 100- dormant and fertilizers are not applied. It is likely that the rates being applied to some greenhouse crops are in excess of plant needs. This is illustrated in Table 5, in which rates for small hanging baskets, chrysanthemum, and poinsettia are substantially greater than other crops. It is also clear that some growers (lower quartile results, Table 5) are producing similar plants with substantially less fertilizer over the same number of weeks. For example, $20-$ to $25-\mathrm{cm}$ poinsettias in Table 5 were produced with $4.77 \mathrm{~kg} \mathrm{~N} / 1000$ plants/year in the lower quartile and with $17.29 \mathrm{~kg} \mathrm{~N} / 1000$ plants/year for the upper quartile. It is likely that growers at the upper end of this range could reduce fertilizer application to the lower or middle quartile rates without negatively impacting plant growth. This would result in greater profit margins from reduced fertilizer input and less potential to release $\mathrm{N}$ or $\mathrm{P}$ to the environment from more efficient fertilization practices. If the plants are not using these excess nutrients, they either remain in the container or are leached when water runs out of the container.

Based on the ranges of $\mathrm{N}, \mathrm{P}$, and $\mathrm{K}$ application rates collected during site visits, a BMP rate can be determined for particular species or types of plants based on current grower practices (Tables 5-7). Best management rates could potentially be reduced to lower or middle quartile values, because these plants were grown in the same amount of time and were of similar quality as plants fertilized at rates used by growers in the upper quartile. Growers could potentially save substantial amounts on fertilizer cost, particularly when using more expensive SRF formulations. Further testing under production conditions are recommended to determine whether the application rate could be reduced even further, which would provide cost and environmental benefits. For example, in Table 5, 25-cm hanging baskets were grown at $1.06 \mathrm{~kg} \mathrm{~N} / 1000$ plants in the lower quartile and $5.96 \mathrm{~kg} \mathrm{~N} / 1000$ plants in the upper quartile. If growers in the upper quartile reduced nutrient inputs by $50 \%$, they would still be supplying adequate nutrition while saving money. Similar results can be seen throughout greenhouse and container nursery production. Field nursery production rates were found to be similar to extension recommendations (Bilderback, 2005) and likely could not be reduced substantially without detrimental effects to plant growth.

No strong correlations were found between container size and application rate for woody perennial categories. Average rates varied between $372-800 \mathrm{~kg} / \mathrm{ha} /$ year for $\mathrm{N}$, $122-241 \mathrm{~kg} / \mathrm{ha} /$ year for $\mathrm{P}_{2} \mathrm{O}_{5}$, and $176-433$ $\mathrm{kg} / \mathrm{ha} /$ year for $\mathrm{K}_{2} \mathrm{O}$ for $1-\mathrm{L}$ to $38-\mathrm{L}$ woody perennials, which encompassed a variety of species grown. This suggests that the application rate of fertilizer per container is based on factors other than container size, such as grower preference, or rate suggestions from fertilizer companies. Growers indicated that fertilizer rates were based on container size and not on the species being grown (data not shown). If so, container nursery growers 


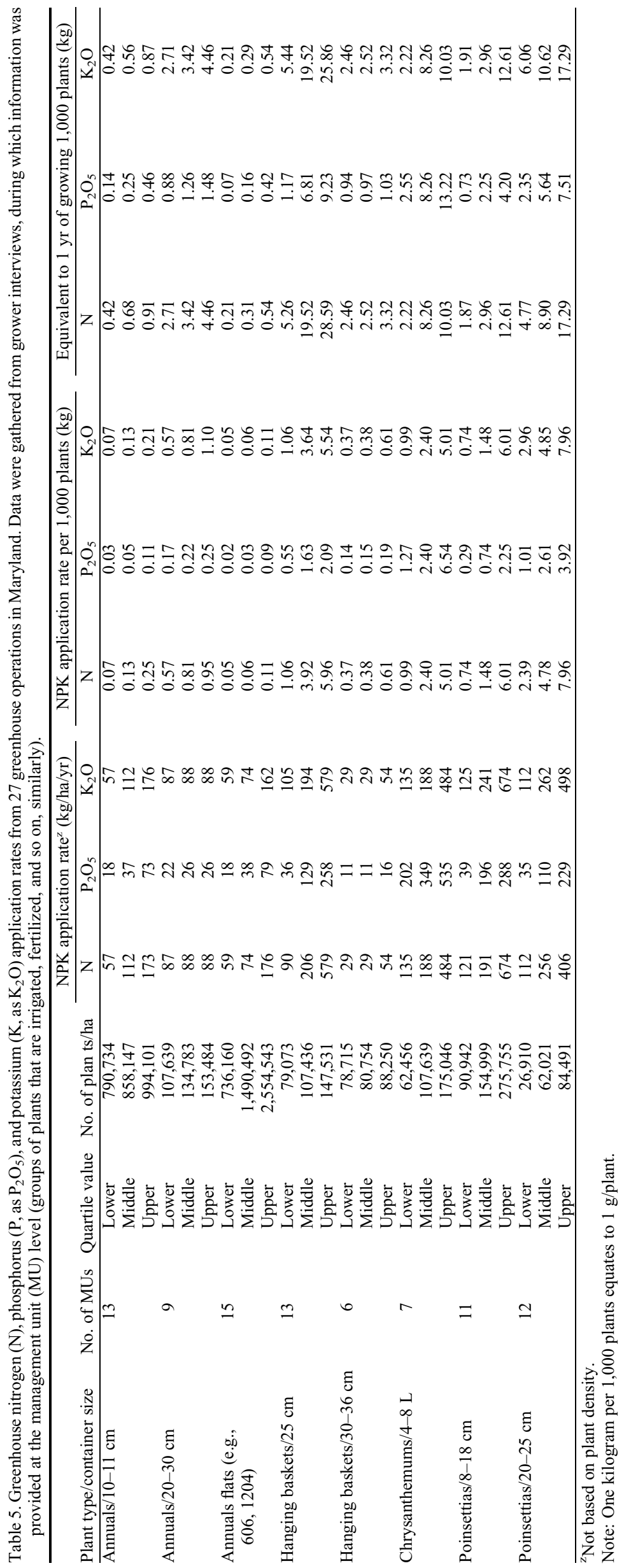

should be able to apply a recommended rate somewhere between the lower and middle quartiles shown in Table 5, and still achieve maximum plant growth rates while minimizing potential nutrient runoff.

Many field nursery operations applied greater ratios of $\mathrm{N}$ compared with $\mathrm{P}_{2} \mathrm{O}_{5}$ and $\mathrm{K}_{2} \mathrm{O}$, which is reasonable considering $\mathrm{N}$ leaches more easily through the soil profile compared with $\mathrm{P}$ and $\mathrm{K}$ ions (Table 7). We concluded from field nursery grower interviews that the main differences were a result of individual preferences for a particular fertilizer $\mathrm{N}: \mathrm{P}_{2} \mathrm{O}_{5}: \mathrm{K}_{2} \mathrm{O}$ ratio and application rate, except in a few operations that were using specific soil test information to inform their nutrient management decisions (data not shown).

The field nursery application rates reported in Tables 1 and 7 were much less compared with the greenhouse and container rates in Tables 1,5 , and 6 , and rates reported for agronomic crops. Average $\mathrm{N}$ rates across field nursery operations listed in Table 1 were $50 \mathrm{~kg} / \mathrm{ha}$ or less, except for one $\mathrm{N}$ rate reported at $67 \mathrm{~kg} / \mathrm{ha} /$ year. Based on this information, a rate of $25-50 \mathrm{~kg} / \mathrm{ha} /$ year $\mathrm{N}$, 6-15 kg/ha/year $\mathrm{P}_{2} \mathrm{O}_{5}$, and $20-40 \mathrm{~kg} / \mathrm{ha} /$ year $\mathrm{K}_{2} \mathrm{O}$ would be recommended for all inground woody plants, based on the information provided in Table 7 . These values are closer to the lower end of the $\mathrm{N}$ recommendations by Bilderback (2005), which suggests $\mathrm{N}$ banding rates of $12-25 \mathrm{~kg} / \mathrm{ha}$ for first-year field stock, $25-51 \mathrm{~kg} / \mathrm{ha}$ in the second year, and $51-102 \mathrm{~kg} / \mathrm{ha}$ for year 3 and beyond, based on 1800 plants/ha. Given the low rates of $\mathrm{N}, \mathrm{P}_{2} \mathrm{O}_{5}$, and $\mathrm{K}_{2} \mathrm{O}$ applied, it is likely that most field nursery operations in Maryland and the surrounding states are not a significant source of $\mathrm{N}$ and $\mathrm{P}$ runoff into the Chesapeake Bay at the plant densities reported by growers. Irrigation water recycling or remediation BMPs implemented by growers would reduce these impacts even more.

Since Majsztrik et al. (2013) reported that field nursery production accounted for 59\% of the acreage under production (32\% container, $7 \%$ other, $2 \%$ greenhouse), the impact of these lesser $\mathrm{N}$ and $\mathrm{P}$ rates for field nursery production on the Chesapeake Bay and its tributaries is most likely reduced compared with many agronomic crops. Nutrient and sediment runoff is also likely minimized by BMPs that were reported, such as grass buffer strips between rows and grass strips at the end of rows, which were seen at all field nursery operations visited. Although there are a number of BMPs that are being used in ornamental field nursery production, there are also a number of concerns based on grower practices. For example, how field nursery producers process an area when mature plants are harvested and new plants are established in a row could impact nutrient and sediment runoff. If rainfall occurs or overhead irrigation is used during and afterbed preparation for new plantings, this could lead to a greater chance of sediment and nutrient loss, compared with what would occur after rows are established. There are 
Table 6. Container nursery nitrogen $(\mathrm{N})$, phosphorus $\left(\mathrm{P}\right.$, as $\left.\mathrm{P}_{2} \mathrm{O}_{5}\right)$ and potassium $\left(\mathrm{K}\right.$, as $\left.\mathrm{K}_{2} \mathrm{O}\right)$ application rates based on 27 site visits to container nursery operations in Maryland. Data were gathered from grower interviews, during which information was provided at the management unit (MU) level (groups of plants that are irrigated, fertilized, and so on, similarly).

\begin{tabular}{|c|c|c|c|c|c|c|c|c|c|}
\hline \multirow[b]{2}{*}{ Plant type/container size } & \multirow[b]{2}{*}{ No. of MUs } & \multirow[b]{2}{*}{ Quartile value } & \multirow[b]{2}{*}{ No. of plants/ha } & \multicolumn{3}{|c|}{ NPK application rate $(\mathrm{kg} / \mathrm{ha} / \mathrm{yr})$} & \multicolumn{3}{|c|}{ NPK application rate per 1,000 plants $(\mathrm{kg})$} \\
\hline & & & & $\mathrm{N}$ & $\mathrm{P}_{2} \mathrm{O}_{5}$ & $\mathrm{~K}_{2} \mathrm{O}$ & $\mathrm{N}$ & $\mathrm{P}_{2} \mathrm{O}_{5}$ & $\mathrm{~K}_{2} \mathrm{O}$ \\
\hline \multirow[t]{3}{*}{ Chrysanthemum/4-8 L } & 3 & Lower & 19,768 & 33 & 11 & 21 & 1.40 & 0.53 & 0.73 \\
\hline & & Middle & 21,498 & 62 & 17 & 38 & 2.55 & 0.80 & 1.20 \\
\hline & & Upper & 34,665 & 92 & 34 & 48 & 2.72 & 0.93 & 1.48 \\
\hline \multirow[t]{3}{*}{ Woody perennials/ $1-4 \mathrm{~L}$} & 22 & Lower & 107,639 & 219 & 94 & 130 & 2.05 & 0.68 & 1.08 \\
\hline & & Middle & 209,297 & 577 & 160 & 280 & 3.01 & 1.21 & 1.62 \\
\hline & & Upper & 271,182 & 915 & 388 & 593 & 3.62 & 1.72 & 2.66 \\
\hline \multirow[t]{3}{*}{ Woody perennials/8 L } & 12 & Lower & 65,727 & 116 & 104 & 67 & 2.48 & 1.24 & 1.04 \\
\hline & & Middle & 85,991 & 386 & 161 & 217 & 4.31 & 1.96 & 2.61 \\
\hline & & Upper & 194,130 & 709 & 273 & 382 & 5.27 & 2.49 & 3.44 \\
\hline \multirow[t]{3}{*}{ Woody perennials/11 L } & 22 & Lower & 34,444 & 220 & 95 & 146 & 7.74 & 2.06 & 3.40 \\
\hline & & Middle & 46,406 & 667 & 185 & 340 & 10.58 & 4.24 & 7.70 \\
\hline & & Upper & 92,569 & 975 & 376 & 498 & 14.71 & 5.91 & 10.20 \\
\hline \multirow[t]{3}{*}{ Woody perennials/19 L } & 21 & Lower & 21,528 & 229 & 72 & 134 & 12.60 & 4.55 & 6.00 \\
\hline & & Middle & 26,910 & 372 & 122 & 176 & 15.31 & 5.15 & 10.21 \\
\hline & & Upper & 29,302 & 756 & 252 & 389 & 19.66 & 6.20 & 11.16 \\
\hline \multirow[t]{3}{*}{ Woody perennials/27 L } & 12 & Lower & 12,120 & 193 & 63 & 112 & 18.50 & 5.86 & 8.35 \\
\hline & & Middle & 14,883 & 422 & 135 & 234 & 29.20 & 9.65 & 17.87 \\
\hline & & Upper & 17,859 & 544 & 183 & 275 & 37.19 & 10.61 & 18.81 \\
\hline \multirow[t]{3}{*}{ Woody perennials/38 L } & 6 & Lower & 6,798 & 405 & 118 & 187 & 38.78 & 11.45 & 17.96 \\
\hline & & Middle & 8,372 & 800 & 241 & 433 & 97.54 & 28.66 & 54.92 \\
\hline & & Upper & 11,362 & 930 & 258 & 568 & 139.40 & 38.72 & 85.19 \\
\hline \multirow[t]{3}{*}{ Woody perennials/57 L } & 6 & Lower & 4,647 & 497 & 148 & 238 & 46.09 & 14.49 & 21.36 \\
\hline & & Middle & 7,367 & 752 & 251 & 334 & 69.93 & 21.57 & 32.83 \\
\hline & & Upper & 9,644 & 1,258 & 360 & 736 & 287.74 & 81.00 & 172.63 \\
\hline
\end{tabular}

${ }_{\mathrm{z}}$ Not based on plant density.

Note: One kilogram per 1,000 plants equates to $1 \mathrm{~g} /$ plant.

Table 7. Field nursery nitrogen $(\mathrm{N})$, phosphorus $\left(\mathrm{P}\right.$, as $\left.\mathrm{P}_{2} \mathrm{O}_{5}\right)$, and potassium $\left(\mathrm{K}\right.$, as $\left.\mathrm{K}_{2} \mathrm{O}\right)$ application rates based on 17 site visits to field nursery operations in Maryland. Data were gathered from grower interviews, during which information was provided at the management unit (MU) level (groups of plants that are irrigated, fertilized, and so on, similarly).

\begin{tabular}{|c|c|c|c|c|c|c|c|c|c|}
\hline \multirow[b]{2}{*}{ Plant type } & \multirow[b]{2}{*}{ No. of MUs } & \multirow[b]{2}{*}{ Quartile value } & \multirow[b]{2}{*}{ No. of plants/ha } & \multicolumn{3}{|c|}{ NPK application rate $(\mathrm{kg} / \mathrm{ha} / \mathrm{yr})^{\mathrm{z}}$} & \multicolumn{3}{|c|}{ NPK application rate $/ 1,000$ plants $(\mathrm{kg})$} \\
\hline & & & & $\mathrm{N}$ & $\mathrm{P}_{2} \mathrm{O}_{5}$ & $\mathrm{~K}_{2} \mathrm{O}$ & $\mathrm{N}$ & $\mathrm{P}_{2} \mathrm{O}_{5}$ & $\mathrm{~K}_{2} \mathrm{O}$ \\
\hline \multirow[t]{3}{*}{ Deciduous trees and shrubs } & 6 & Lower & 1,794 & 20 & 0 & 0 & 8.40 & 0.00 & 0.00 \\
\hline & & Middle & 2,406 & 28 & 9 & 9 & 15.62 & 3.00 & 3.00 \\
\hline & & Upper & 2,722 & 34 & 21 & 21 & 18.10 & 10.01 & 10.01 \\
\hline \multirow[t]{3}{*}{ Evergreen trees and shrubs } & 13 & Lower & 2,471 & 0 & 0 & 0 & 0.00 & 0.00 & 0.00 \\
\hline & & Middle & 4,377 & 7 & 0 & 0 & 2.39 & 0.00 & 0.00 \\
\hline & & Upper & 4,305 & 28 & 9 & 17 & 15.62 & 2.92 & 5.85 \\
\hline \multirow{3}{*}{$\begin{array}{l}\text { Mixed deciduous and } \\
\text { evergreen trees and shrubs }\end{array}$} & 73 & Lower & 1,794 & 38 & 9 & 9 & 18.46 & 4.71 & 4.70 \\
\hline & & Middle & 2,250 & 67 & 19 & 19 & 34.53 & 9.00 & 9.26 \\
\hline & & Upper & 2,152 & 107 & 26 & 26 & 57.29 & 13.88 & 14.28 \\
\hline
\end{tabular}

${ }^{\mathrm{z}}$ Not based on plant density.

Note: One kilogram per 1,000 plants equates to $1 \mathrm{~g} / \mathrm{plant}$.

other practices, such as planting cover crops, minimizing the time that soil is left unplanted, and maintaining grass buffers during field renovation, that could also reduce nutrient and sediment losses.

\section{Conclusions}

The information presented here is the most comprehensive and detailed analysis of nutrient and irrigation practices of commercial nursery and greenhouse operations available for Maryland or anywhere in the United States, to our knowledge. Fertilization rates are reported for a number of greenhouse, container nursery, and field management scenarios, which can be used as a guide for extension specialists and growers to determine how their fertilizer practices compare with others in the industry. Because fertilizer application rates were reported directly by growers based on actual practice, these rates should be directly applicable to growers producing similar plants in similar climates. We found that greenhouse and container nursery operations that applied fertilizers at greater rates (upper quartile) could likely reduce fertilization rates by a half or more, without negatively impacting plant growth, as other growers were producing similar plants of similar quality with substantially less fertilizer. Reducing fertilization rates applied by ornamental operations would likely have a substantial impact on both cost savings from reduced fertilizer use and an environmental benefit from reduced nutrient leaching, particularly from greenhouse and container nursery production, and, to a lesser degree, field nursery production.

Supplemental irrigation is required to optimize plant growth rates both in greenhouse and container nursery operations. In field nursery operations, irrigation is used to increase plant growth and survival during early stages of production, and during extended periods of dry conditions during the later stages of production. Similar trends were seen for both irrigation and nutrient management. Operations in the upper quartile could likely reduce irrigation by half or more without negatively impacting plant growth. Plant quality may increase as a result of reduced disease incidence from reduced irrigation. Because water management plays an integral role in operational efficiency, nutrient leaching, and sediment runoff, it is an important area for future research and grower education. As freshwater resources continue to be an area of concern in Maryland and across the country, water management will continue to be a focus for both growers and researchers now and into the future.

\section{Literature Cited}

Bailey, D.A., W.C. Fonteno, and P.V. Nelson. 2000. Greenhouse substrates and fertilization. North Carolina State University Department of Horticultural Science, Raleigh, NC.

Belayneh, B.E., J.D. Lea-Cox, and E. Lichtenberg. 2013. Costs and benefits of implementing sensor-controlled irrigation in a commercial pot-in-pot container nursery. HortTechnology 23:760-769.

HortScience Vol. 53(9) September 2018 
Bilderback, T. 2005. Conservation and nutrient management practices for field production of nursery stock, p. 25-33. North Carolina State University, Raleigh, NC.

Blalock, L.L. and M.D. Smolen. 1990. Estimation of nonpoint source loading factors in the Chesapeake Bay watershed model. North Carolina State University, Raleigh, NC.

Cabrera, R.I. 1997. Comparative evaluation of nitrogen release patterns from controlledrelease fertilizers by nitrogen leaching analysis. HortScience 32:669-673.

Cabrera, R.I. 2003. Nitrogen balance for two container-grown woody ornamental plants. Scientia Hort. 97:297-308.

Chappell, M., S.K. Dove, M.W. van Iersel, P.A. Thomas, and J. Ruter. 2013. Implementation of wireless sensor networks for irrigation control in three container nurseries. HortTechnology 23:747-753.

Dawson, A., B. Rater, and D. Hawks. 2009. Maryland horticulture industry economic profile, $\mathrm{p}$. 35. In: U.S. Department of Agriculture (ed.). The Maryland horticulture industry: A statistical profile and economic survey 2007. Maryland Agricultural Statistics Service, MD.

Delgado, J.A. and W.C. Bausch. 2005. Potential use of precision conservation techniques to reduce nitrate leaching in irrigated crops. J. Soil Water Conserv. 60:379-387.

Du, C.-W., J.-M. Zhou, and A. Shaviv. 2006. Release characteristics of nutrients from polymer-coated compound controlled-release fertilizers. J. Polym. Environ. 14:223-230.

Environmental Protection Agency. 2009. Bay barometer: A health and restoration assessment of the Chesapeake Bay watershed in 2008, p. 40. In: Environmental Protection Agency (ed.). Chesapeake Bay Program. <http://www.chesapeakebay. net/content/publications/cbp_34915.pdf $>$.

Hansen, C.W. and J. Lynch. 1998. Response to phosphorus availability during vegetative and reproductive growth of chrysanthemum: II. Biomass and phosphorus dynamics. J. Amer. Soc. Hort. Sci. 123:223-229.

Harris, R.W. 1992. Root-shoot ratios. J. Arboric. 18:39-42.

Headley, T.R., D.O. Huett, and L. Davison. 2001. The removal of nutrients from plant nursery irrigation runoff in subsurface horizontal-flow wetlands. Water Sci. Technol. 44:77-84.

Hong, C., J.D. Lea-Cox, D.S. Ross, G.W. Moorman, P.A. Richardson, S.R. Ghimire, and P. Kong. 2009. Containment basin water quality fluctuation and implications for crop health management. Irr. Sci. 27:485-496.

Huett, D.O. and B.J. Gogel. 2000. Longevities and nitrogen, phosphorus, and potassium release patterns of polymer-coated controlled-release fertilizers at $30^{\circ} \mathrm{C}$ and $40^{\circ} \mathrm{C}$. Commun. Soil Sci. Plant Anal. 31:959-973.

Hutson, S.S., N.L. Barber, J.F. Kenny, K.S. Linsey, D.S. Lumia, and M.A. Maupin. 2004. Estimated use of water in the United States in 2000, p. 52.
In: U.S. Department of the Interior (ed.). U.S. Geological Survey, Reston, VA.

Ku, C.S.M. and D.R. Hershey. 1997a. Growth response, nutrient leaching and mass balance for potted poinsettia: I. Nitrogen. J. Amer. Soc. Hort. Sci. 122:452-458.

Ku, C.S.M. and D.R. Hershey. 1997b. Growth response, nutrient leaching, and mass balance for potted poinsettia: II. Phosphorus. J. Amer. Soc. Hort. Sci. 122:459-464.

Lea-Cox, J.D. 2012. Using wireless sensor networks for precision irrigation scheduling. In: M. Kumar (ed.). Problems, perspectives and challenges of agricultural water management. <http://www.intechopen.com/books/ problems-perspectives-and-challenges-ofagricultural-water-management/using-sensornetworks-for-precision-irrigation-control $>$.

Lea-Cox, J.D., W.L. Bauerle, M.W. van Iersel, G.F. Kantor, T.L. Bauerle, E. Lichtenberg, D.M. King, and L. Crawford. 2013. Advancing wireless sensor networks for irrigation management of ornamental crops: An overview. HortTechnology 23:717-724.

Lea-Cox, J.D. and D.S. Ross. 2001. A review of the Federal Clean Water Act and the Maryland Water Quality Improvement Act: The rationale for developing a water and nutrient management planning process for container nursery and greenhouse operations. J. Environ. Hort. 19:226-229.

Lea-Cox, J.D., D.S. Ross, and K.M. Teffeau. 2001. A water and nutrient management planning process for container nursery and greenhouse production systems in Maryland. J. Environ. Hort. 19:230-236.

Majsztrik, J. 2011. Modeling nitrogen, phosphorus and water dynamics in greenhouse and nursery production systems. Univ. of Maryland, College Park, PhD Diss.

Majsztrik, J. and J.D. Lea-Cox. 2013. Water quality regulations in the Chesapeake Bay: Working to more precisely estimate nutrient loading rates and incentivize best management practices in the nursery and greenhouse industry. HortScience 48:1097-1102.

Majsztrik, J.C., A.G. Ristvey, and J.D. Lea-Cox. 2011. Water and nutrient management in the production of container-grown ornamentals. Hort. Rev. 38:253-297.

Majsztrik, J., A. Ristvey, E. Lichtenberg, and J. Lea-Cox. 2013. Maryland horticulture industry economic profile (2012), p. 40. Maryland Nursery and Landscape Association. <http://mdnla. membershipsoftware.org/files/Final\%20Report \%20-\%20Dec\%2023\%202013\%283\%29.pdf>.

Mangiafico, S.S., J. Newman, D.J. Merhaut, J. Gan, B. Faber, and L. Wu. 2009. Nutrients and pesticides in stormwater runoff and soil water in production nurseries and citrus and avocado groves in California. HortTechnology 19:360-367.

Ott, R.L. and M. Longnecker. 2001. An introduction to statistical methods and data analysis. Thomson Learning New York, NY.
Owen, J.S., Jr., S. Warren, T. Bilderback, and J. Albano. 2008. Phosphorus rate, leaching fraction and substrate influence on influent quality, effluent nutrient content, and response of a containerized woody ornamental crop. HortScience 43:906-912.

Peterson, T.A. and G.E. Varvel. 1989. Crop yield as affected by rotation and nitrogen rate: III. Corn. Agron. J. 81:735-738.

Ristvey, A.G. 2004. Water and nutrient dynamics in container-nursery production systems. Univ. Maryland, College Park, PhD Diss.

Ross, D.S., J.D. Lea-Cox, and K.M. Teffeau. 2002. The importance of water in the nutrient management process. Proc. Southern Nursery Assoc. Res. Conf. 46:574-577.

Sammons, J.D. 2008. Use of near-zero leachate irrigation systems for container production of woody ornamental plants. Ohio State Univ., PhD Diss.

Sandrock, D.R., R.D. William, and A.N. Azarenko. 2004. Group-based on-site active learning (GOAL): Technique for investigating nitrogen management in container nurseries. Hort Technology 14:442-448.

Santos, K.M., P.R. Fisher, and W.R. Argo. 2008. A survey of water and fertilizer management during cutting propagation. HortTechnology 18:597-604.

Sincock, J. 2010. Chesapeake Bay total maximum daily load (TMDL) fact sheet. Environmental Protection Agency, Water Protection Division, Washington, DC.

Stewart, W.M., D.W. Dibb, A.E. Johnston, and T.J. Smyth. 2005. The contribution of commercial fertilizer nutrients to food production. Agron. J. 97:1-6.

U.S. Department of Agriculture. 2010. Census of horticultural specialties (2009). 15 Dec. 2010. $<$ http://www.agcensus.usda.gov/Publications/2007/ Online_Highlights/Census_of_Horticulture/index. asp>.

van Iersel, M.W., M. Chappell, and J.D. Lea-Cox. 2013. Sensors for improved efficiency of irrigation in greenhouse and nursery production. HortTechnology 23:735-746.

Warren, S.L. and T.E. Bilderback. 2004. Irrigation timing: Effect on plant growth, photosynthesis, water-use efficiency, and substrate temperature. Acta Hort. 644:29-37.

Warsaw, A.L., R.T. Fernandez, B.M. Cregg, and J.A. Andresen. 2009. Container-grown ornamental plant growth and water runoff nutrient content and volume under four irrigation treatments. HortScience 44:1573-1580.

Williams, K.A. and P.V. Nelson. 1996. Modifying a soilless root medium with aluminum influences phosphorus retention and chrysanthemum growth. HortScience 31:381-384.

Yeager, T., R. Wright, D. Fare, C. Gilliam, J. Johnson, T. Bilderback, and R.A. Zondag. 1993. Six state survey of container nursery nitrate nitrogen runoff. J. Environ. Hort 11:206-208. 